DOI 10.20396/temáticas.v15i29.13647

\title{
O PAPEL DO POLÍTICO E DAS FORÇAS PRODUTIVAS NA TEORIA DA TRANSIÇÃO SOCIALISTA EM LÊNIN: NOTAS INTRODUTÓRIAS*
}

Angela Lazagna**

RESUMO: Neste artigo, buscar-se-á apresentar qual o lugar do político, no pensamento de Lênin, na reprodução do modo de produção capitalista e na transição socialista. Num segundo momento, tentar-se-á discutir o papel das forças produtivas e do taylorismo, no pensamento de Lênin, na transição socialista, a partir da crítica ao determinismo tecnológico. Tem-se, como ponto de partida para essa reflexão, alguns conceitos desenvolvidos, tanto por autores que protagonizaram o debate promovido pela corrente althusseriana nas décadas de 1960 e 1970 , como por aqueles que desenvolveram tais conceitos acerca do lugar do político na teoria marxista da história.

PALAVRAS-CHAVE: Forças Produtivas, Estado, Política, Transição, Socialismo.

Lênin, ao refletir sobre a questão do Estado, desenvolve muitas das teses formuladas por Marx e Engels acerca da centralidade do papel da ditadura do proletariado na transição socialista. Debatendo com muitas das obras desses

* Este artigo é uma versão mais desenvolvida do trabalho apresentado no Seminário Lenin: 80 anos, ocorrido entre 23 a 24 de novembro e 02 de dezembro, em 2004, no Instituto de Filosofia e Ciências Humanas (IFCH), da Universidade Estadual de Campinas (UNICAMP), evento organizado pelo Centro de Estudos Marxistas (Cemarx) em parceria com o Instituto LatinoAmericano de Estudos Sócio-Econômicos (Ilaese), com a revista Crítica Marxista e com a revista Outubro. Gostaria de agradecer aos pareceristas anônimos pelas proveitosas sugestões concedidas a este trabalho. Os erros e imperfeições que porventura nele subsistam são de minha responsabilidade.

** Doutoranda em Ciência Política na Universidade Estadual de Campinas (UNICAMP). 
autores - nas quais, como diria mais tarde Poulantzas, um tratamento teórico do político pode ser apreendido através da presença de "conceitos em estado prático" - Lênin desenvolve a descoberta marxiana de uma "nova forma política" (Marx apud: Boron, 2003: 227) para a superação do modo de produção capitalista: a necessidade de destruição do Estado.

“...se o proletariado precisa do Estado como organização especial da violência contra a burguesia, então daqui impõese uma conclusão: será concebível a criação de tal organização sem suprimir previamente, sem destruir a máquina do Estado que a burguesia criou para si própria? É a esta conclusão que conduz diretamente o Manifesto Comunista e é desta conclusão que Marx fala quando faz o balanço da experiência da revolução de 1848-1851" (Lênin, 1980b: 239).

A partir daí, Lênin encontrará o caminho para desenvolver suas teses acerca do papel do Estado na transição socialista. Ao afirmar que o Estado capitalista é suprimido pela revolução proletária e o que se extingue é um "semi-Estado", qual seja, o Estado sob a ditadura do proletariado (Lênin, 1980b: 234), Lênin dá sua grande contribuição, não somente à experiência histórica da Revolução bolchevique, mas, sobretudo, à construção de uma teoria da transição socialista, ao explicitar que devido ao seu caráter capitalista, esse Estado deve der destruído através de uma revolução política.

\footnotetext{
${ }^{1}$ Poulantzas (1970: 12) ao se referir aos textos clássicos do marxismo (Marx, Engels, Lênin e Gramsci) afirma que o que se encontra nessas obras “...é um corpo ordenado de conceitos no 'estado prático', quer dizer, presentes no discurso e destinados, pela sua função, a dirigir diretamente a prática política em uma conjuntura concreta, mas não teoricamente elaborados; ou ainda elementos de conhecimento teórico da prática política e da superestrutura do Estado, isto é, conceitos elaborados, mas não inseridos em um discurso teórico sistemático; ... finalmente, uma concepção que sustenta a produção dos seus conceitos com grande rigor ... mas também de forma certamente aleatória, característica de todo o pensamento que não é contemporâneo de si mesmo, isto é, que não é sistematicamente explícito nos seus princípios” (tradução minha, AL).
} 
"O proletariado não pode derrubar a burguesia sem ter conquistado primeiro o poder político, sem ter alcançado a dominação política, sem ter transformado o Estado em 'proletariado organizado como classe dominante', e que este Estado proletário começará a extinguir-se logo após a sua vitória, porque numa sociedade sem contradições de classe o Estado é desnecessário e impossível" (Lênin, 1980b: 241).

É neste sentido, pois, que Martorano (2002: 81) afirma que as duas teses teóricas centrais de Lênin sobre a questão do Estado são “... a da necessidade de destruição do Estado burguês pela revolução proletária para se poder iniciar a passagem para o comunismo, e a da ditadura do proletariado se configurando como um semi-Estado".

Lênin defende que a fase da transição socialista deve estar submetida

“... ao mais rigoroso controle por parte da sociedade e por parte do Estado sobre a medida do trabalho e a medida do consumo, mas este controle deve começar com a expropriação dos capitalistas, com o controle dos capitalistas pelos operários, e deve ser exercido não por um Estado de funcionários, mas pelo Estado dos operários armados” (Lênin, 1980b: 288).

Esse semi-Estado, ao substituir as tarefas burocráticas que predominavam no Estado de tipo capitalista, por uma democracia de massa; ao submeter o mandato dos seus funcionários ao voto popular; ao igualar os vencimentos desses funcionários aos do operário (Boito Jr., 2004: 78), medidas essas tomadas na experiência histórica da Comuna de Paris $^{2}$ e que influenciaram as teses desenvolvidas por Lênin, tem a função, como bem mostrou Martorano (2002: 94), de impedir que a classe dominada possa exercer a repressão sobre a classe dominante justamente para que esta não reconquiste o poder, como também para a proteção comum dos meios de produção que foram expropriados dos capitalistas.

\footnotetext{
${ }^{2}$ Veja-se, a esse respeito, Boito Jr. (2001), Martorano (2001) e Quartim de Moraes (2001).
} 
Mas a expropriação dos capitalistas, segundo Lênin, abriria, pois, a possibilidade "de um desenvolvimento gigantesco das forças produtivas", mas não eliminaria prontamente "uma das principais fontes da desigualdade social": a "oposição entre o trabalho intelectual e o trabalho manual" (Lênin, 1980b: 287), o que somente ocorreria no comunismo, no qual o Estado terse-ia se extinguido. Para se chegar até esta etapa superior, Lênin indica que o registro e o controle, não somente das tarefas administrativas do Estado, mas da sociedade como um todo - "aparelho dos correios, das estradas de ferro, das grandes fábricas, do grande comércio, dos bancos, etc." - deveriam ser obra de "todo o povo armado", já que essas tarefas já teriam sido simplificadas pelo próprio capitalismo: “O registro disto, o controle disto, foram simplificados em extremo pelo capitalismo, até operações extraordinariamente simples de vigilância acessíveis a qualquer pessoa alfabetizada..." (Lênin, 1980b: 290), de modo que "Toda a sociedade será um único escritório e uma fábrica, com igualdade de trabalho e igualdade de salário" (Lênin, 1980b: 291). Neste processo de registro e controle, os especialistas burgueses deveriam ser submetidos ao controle operário e não mais ao controle dos capitalistas (Lênin, 1980b: 290).

Portanto, segundo Martorano (2002: 41-42), Lênin não considera que a simples estatização dos meios de produção, ou seja, a expropriação jurídica das fábricas dos capitalistas e das terras dos proprietários fundiários já significaria a instauração de novas relações de produção de caráter socialista, apontando, sem muita precisão, a necessidade de uma "reorganização socialista" da produção. Para além dessa constatação importantíssima - a da não identificação entre estatização dos meios de produção e socialismo - Lênin também ressalta que a luta de classes ainda continua sob a ditadura do proletariado.

“... a ditadura do proletariado é também um período de luta de classes, que é inevitável enquanto as classes não tiverem sido suprimidas e que muda as suas formas, tornando-se particularmente encarniçada e particularmente específica durante os primeiros tempos após o derrubamento do capital. Uma vez conquistado o poder político, o proletariado não cessa a sua luta de classe, 
antes a continua até a supressão das classes, mas naturalmente noutras condições, sob outras formas e com outros meios" (Lênin, 1980d: 150, grifo meu, A.L.)

A realização do comunismo somente pode acontecer, de acordo com Lênin, com a supressão das classes sociais; e essa supressão só pode decorrer da abolição da “...propriedade privada dos meios de produção, ... [da supressão da] diferença entre cidade e o campo, ... [do fim da] diferença entre os trabalhadores manuais e intelectuais", o que seria "uma obra muito longa", cujo fim seria a superação completa do Estado (Lênin, 1980d: 150).

Contudo, seria interessante, para além da rápida exposição da concepção de Lênin do papel do político na transição socialista, para que suas teses ganhem uma sustentação teórica mais sólida, apresentarmos sua resposta à seguinte pergunta: o que é o Estado?

Segundo Lênin, "As duas instituições mais características desta máquina de Estado são: o funcionalismo e o exército permanente" (1980b: 241) tendo em vista que, neste Estado, "Os homens dividem-se em governados e em especialistas de governação, que se elevam acima da sociedade e aos quais se chama governantes, representantes do Estado" (1980c: 181, grifo meu, A. L.).

\begin{abstract}
"O desenvolvimento, o aperfeiçoamento, a consolidação deste aparelho burocrático e militar prosseguem através de todas as revoluções burguesas que a Europa viu muitas vezes desde o tempo da queda do feudalismo. Em particular, precisamente a pequena burguesia é atraída para o lado da grande e é submetida a ela, em grau significativo, por meio deste aparelho, que dá às camadas superiores do campesinato, dos pequenos artesãos, dos comerciantes, etc., lugarzinhos relativamente cômodos, tranqüilos e honrosos, que colocam os seus possuidores acima do povo" (Lênin, 1980b: 241-242).
\end{abstract}

O Estado capitalista é uma máquina de repressão, “...um aparelho especial para a aplicação sistemática da violência e para a submissão dos homens pela violência" (Lênin, 1980c: 179); mas, para além do seu caráter repressivo, 
possui a particularidade de proclamar a liberdade de todas as classes, inclusive dos trabalhadores; ou seja, Lênin percebe a função do Estado, através de efeitos ideológicos que lhe são característicos, de manutenção da coesão de uma formação social e de garantir a reprodução das condições de produção desse sistema, o que determina a dominação de uma classe sobre as outras ${ }^{3}$. A explicação histórica do Estado é o que possibilita, segundo Lênin, a compreensão do motivo do seu surgimento. Lênin constata que o Estado só pode existir a partir do surgimento das sociedades divididas em classes, (Lênin, 1980c: 179) o que pressupõe a existência dos proprietários dos meios de produção e dos não proprietários dos meios de produção, sendo esse Estado “...uma máquina para sustentar a dominação de uma classe sobre a outra”, o que torna impossível essa dominação sem "um aparelho permanente de coação" (Lênin, 1980c: 182). A análise da “... passagem da sociedade das formas primitivas de escravidão à servidão e, finalmente, ao capitalismo..." (Lênin, 1980c: 180) é o que explicita as especificidades dos mais diversos tipos de Estado das sociedades divididas em classes. ${ }^{4} \mathrm{O}$ que nos importa, pois, ressaltar aqui é que aflora dessa análise de Lênin a constatação de que cada um desses modos de produção - e não caberia referenciar os modos de produção précapitalistas baseados na propriedade coletiva dos meios de produção e, portanto, não divididos entre classes sociais antagônicas já que eles, de acordo com Lênin, não possuiriam Estado justamente por não estarem divididas em classes - possui um tipo particular de Estado na sua forma de organização.

\footnotetext{
${ }^{3}$ Foi Armando Boito Jr. quem me chamou a atenção para estas concepções de Lênin do Estado de tipo capitalista presentes, particularmente, no texto Sobre o Estado e da sua relação com as teses desenvolvidas por Poulantzas $(1970,1975)$ acerca do papel do Estado na reprodução do modo de produção capitalista.

${ }^{4}$ Não cabe aqui discutirmos se a concepção leliniana da passagem de uma sociedade a outra, ou seja, da transição de um modo de produção ao outro compartilha de uma visão linear, etapista, teleológica do desenvolvimento histórico. Gostaríamos de referenciar o artigo de Vanzulli (2006), que a partir de uma releitura do texto Formações econômicas pré-capitalistas, traz uma importante contribuição sobre a visão de Marx da transição ("passagem”) de um modo de produção a outro. Veja-se, também, o importante debate no qual encontramos diversas teses acerca de quais condições propiciaram o surgimento do capitalismo, o qual pode ser encontrado em: Sweezy (1977). Esse debate foi resgatado por Mariutti (2004). Veja-se, também, Lazagna (2005a).
} 
“...cada um destes grandes períodos da história humana - o da escravidão, o da servidão e o do capitalismo - abrange dezenas e centenas de séculos e apresenta uma tal quantidade de formas políticas, de doutrinas, opiniões e revoluções políticas diferentes..." (Lênin, 1980c: 181).

E como seria possível compreender toda essa variedade, “....relacionada com as doutrinas políticas, filosóficas e outras dos sábios e políticos burgueses"? Segundo Lênin, isto só é possível se for estabelecido "...como fio condutor fundamental [dessa compreensão], ... esta divisão da sociedade em classes, à mudança das formas de dominação de classe" (Lênin, 1980c: 181, grifo meu, A. L.). Ao comparar o Estado escravista e o Estado feudal, Lênin constata mais semelhanças do que diferenças entre eles. No que tange as diferenças, enquanto os escravos eram considerados uma "coisa" de completa propriedade do escravista, sendo a lei o que "consagrava esta concepção..." (Lênin, 1980c: 180), o camponês servo não era considerado uma propriedade do senhor feudal; o "... latifundiário feudal ... apenas tinha o direito ao seu trabalho e a coagi-lo ao cumprimento de certas obrigações” (Lênin, 1980c: 180).

É o surgimento do modo de produção capitalista que evidencia uma diferença entre este e os modos de produção escravista e feudal, bem como explicita o que há de comum entre estes últimos: tanto os escravos quanto os servos não eram considerados cidadãos, o que somente passa a ocorrer com o advento do capitalismo.

"A modificação da forma de exploração transformou o Estado escravista em feudal... $\mathrm{Na}$ sociedade escravista reinava a absoluta falta de direitos do escravo, ele não era reconhecido como homem; na sociedade feudal reinava a adscrição do camponês à terra" (Lênin, 1980c: 183, grifo meu, A. L.).

Mas a classe capitalista que surge, segundo Lênin, na sociedade feudal “...à medida que se desenvolvia o comércio e surgia o mercado mundial, à medida que se desenvolvia a circulação monetária...” (Lênin, 1980c: 180), no 
modo de produção capitalista é a compradora da força de trabalho dos nãoproprietários dos meios de produção. E o que possibilita essa compra e venda de trabalho entre partes iguais é justamente o direito de tipo capitalista.

“... [na sociedade capitalista] os cidadãos se tornaram como que iguais, de tal modo que desapareceu a antiga divisão em escravistas e escravos e que cada um possuía - tanto aqueles que possuíam a terra em propriedade privada como aqueles que não a possuíam nada senão a força dos seus braços -, todos são iguais perante a le?" (Lênin, 1980c: 185, grifo meu, A. L.).

Lênin prossegue na sua análise, explicitando o quão complexa é a função do Estado no desenvolvimento de uma formação social na qual vigora o modo de produção capitalista:

"A lei protege todos por igual, protege a propriedade dos que a têm dos atentados contra a propriedade por parte da massa que, não tendo propriedade nenhuma, não tendo nada além dos seus braços, gradualmente cai na miséria, se arruína e transforma em massa proletária ... Esta sociedade ergueuse contra o feudalismo ... com a palavra de ordem de liberdade. Mas era liberdade para os proprietários (...) O Estado proclama o sufrágio universal, e ... declara que não é um Estado de classe" (Lênin, 1980c: 185-186).

Mesmo reconhecendo que a república democrática e o sufrágio universal são um progresso em relação ao regime feudal e escravocrata, pois “...deram a possibilidade ao proletariado de atingir a união e a coesão que ele têm, de constituir as fileiras harmoniosas e disciplinadas que travam uma luta sistemática contra o capital..." (Lênin, 1980c: 188), esse Estado, independente dos seus regimes políticos, continua sendo “...uma máquina destinada a permitir aos capitalistas ... a possibilidade de manter o seu poder sobre a classe operária e camponesa" (Lênin, 1980c: 186)5. Com esta observação, não pretendemos

\footnotetext{
${ }^{5}$ Lênin (1980c) aponta as seguintes características no Estado no modo de produção escravista: "A monarquia, como poder de uma só pessoa, a república, como ausência de qualquer poder não eletivo; a aristocracia, como poder do povo ... Todas estas diferenças surgiram na época da
} 
sugerir que Lênin desconsidera a importância de uma análise marxista sobre os mais diversos regimes políticos bem como a sua importância para a luta dos trabalhadores contra o capitalismo. O que queremos evidenciar é que o Estado de tipo capitalista, em última instância, possui a função de manutenção da coesão de uma formação social para que seja possível a reprodução do modo de produção capitalista predominante nesta formação.

É na linha de argumentação sobre essa função do Estado que as considerações de Lênin sobre tal questão nos chamam mais a atenção: ele ressalta que não são somente "as pessoas que se encontram diretamente dependentes da burguesia" ou "aqueles que se encontram sob o jugo do capital" ou os "que foram subornados por esse capital” (Lênin, 1980c: 188) que concebem esse Estado como "expressão da vontade popular", "a resultante das decisões de todo o povo", "a expressão da vontade nacional”, mas "...também as pessoas que se encontram simplesmente sob a influência dos preconceitos da liberdade burguesa...” (Lênin, 1980c: 188 - grifou meu, A. L.). Mas, por qual motivo consideramos a importância da constatação de Lênin de que o Estado capitalista, para além da sua função repressora, apresenta também a função de garantir a coesão de uma determinada formação social na qual vigora o modo de produção capitalista, ao atuar enquanto o representante universal de todas as classes? Justamente para explicitarmos que Lênin, primeiramente, preocupava-se com uma análise científica do nível político no modo de produção capitalista, pois a importância de uma teoria marxista do Estado reside no fato de que, através dela “...vereis sempre ... a luta das diferentes classes entre si; a luta que se reflete ou encontra a sua expressão na luta de concepções sobre o Estado, na apreciação do papel e da importância do Estado" (Lênin, 1980c: 178). Em segundo lugar, Lênin, ao reconhecer essa função do Estado de tipo capitalista, acaba por romper com uma concepção instrumentalista que o concebe enquanto um simples agente da repressão de uma classe pela outra. Por fim, Lênin explicita a necessidade de

escravidão. Apesar destas diferenças, o Estado da época da escravidão era um Estado escravista quer fosse uma monarquia ou uma república aristocrática democrática” (...) [também onde predominava o regime de escravidão teve-se] a monarquia e a república, embora esta estivesse uma expressão mais fraca..." (Lênin, 1980c: 183-184). 
uma revolução política para que se inicie o processo de transição socialista. Consideramos, portanto, que estes três aspectos do seu pensamento acabam por fortalecer os alicerces teóricos do conceito de ditadura do proletariado. Analisar, pois, teoricamente o político enquanto nível específico que constitui o modo de produção capitalista permite-nos o entendimento do lugar ocupado e da função exercida pelo político na reprodução do modo de produção capitalista, através da sua função de manter a coesão de uma formação social por ele dominada; essa compreensão pode nos fornecer também os instrumentos para uma análise, mesmo que num âmbito geral, das formas da sua transformação. Por fim, o tratamento do político enquanto nível de um modo de produção determinado pode ser desdobrado numa análise do papel do político na transição socialista. Importa ressaltar que tais idéias foram desenvolvidas por alguns autores pertencentes à corrente althusseriana, nas décadas de 1960 e $1970^{6}$.

A corrente althusseriana se colocou a tarefa de reconstruir a teoria marxista da história, ou seja, o materialismo histórico, ressaltando a importância da análise do lugar da política - compreendida como o lugar da prática política e da estrutura jurídico-política do Estado tanto na reprodução de um modo de produção determinado quanto nos processos de transição de um modo de produção a outro - e da determinação em última instância do econômico na teoria marxista da história ${ }^{7}$. Reconheciam, pois, como necessária a aplicação

\footnotetext{
${ }^{6}$ Saes (1994) observa que foram, principalmente Louis Althusser, Étienne Balibar e Alain Badiou os que se envolveram mais diretamente com a tarefa de reconstruir a teoria marxista da história. Porém, ausenta-se, nos trabalhos dos autores pertencentes a essa corrente, uma exposição mais sistemática no que se refere à teoria da transição de um modo de produção a outro. De qualquer forma, é principalmente Balibar (1970), bem como Bettelheim (1969) os que acabam por priorizar a transição de um modo de produção a outro como objeto de estudo.

${ }^{7}$ Veja-se o artigo de Saes (1994), no qual, ao analisar a possibilidade de operacionalidade dos conceitos - desenvolvidos pela corrente althusseriana - de "determinação em última instância", "dominância" e "implicação recíproca" na relação entre as estruturas que compõem o modo de produção, acaba por retificar algumas das teses dessa corrente, relacionando os dois primeiros conceitos à teoria da transição de um modo de produção ao outro e o último, à análise da reprodução do modo de produção. Para esta sintética exposição de alguns conceitos desenvolvidos pela corrente althusseriana, importa ressaltar que seguimos a linha argumentativa de Saes desenvolvida no seu artigo.
} 
dessa teoria nas análises não só das sociedades capitalistas, mas “...das próprias 'sociedades pós-revolucionárias'; isto é, sociedades que passaram por processos revolucionários liderados por correntes políticas que afirmavam agir em nome da doutrina marxista” (Saes, 1994: 39).

Segundo Althusser (1979: 202), o materialismo dialético-histórico nova problemática fundada por Marx - possibilita a construção
“... de uma teoria dos diferentes niveis específicos da prática bumana (prática econômica, política, ideológica, científica nas suas articulações próprias, fundadas nas articulações específicas da unidade da sociedade humana)."

$\mathrm{Na}$ teoria marxista da história os "sujeitos" da história são, pois, as "sociedades humanas dadas" que se apresentam como totalidades estruturadas ou modos de produção, sendo sua unidade constituída por um tipo específico de complexidade que põe em jogo o nível econômico e o nível político (Althusser, 1979). Estes níveis estão condicionados por uma relação de implicação recíproca, o que significa dizer que o funcionamento/reprodução de um nível determina e é determinado pelo funcionamento/reprodução de outro nível. Dito de outra forma, "...a implicação recíproca - ou condicionamento recíproco das instâncias do modo de produção significa que cada instância se configura como condição necessária à reprodução das demais" (Saes, 1998: 46). Cada modo de produção implica a presença de forças produtivas e relações de produção determinadas, ou seja, apresentam uma organização social da produção e suas correspondentes formas ideológicas. Portanto, é a transformação completa dos seus níveis o que promove a transição de um modo de produção a outro (Bettelheim, 1969: 24). A análise de um modo de produção determinado através dos seus níveis específicos permite a construção de teorias regionais referentes a um determinado modo de produção, como, por exemplo, a teoria regional do econômico e/ou a teoria regional do político do modo de produção capitalista.

Para desenvolvermos a tese que atribui ao Estado de tipo capitalista uma função ideológica, tomaremos como referência alguns dos conceitos 
formulados por Poulantzas (1970) relacionados ao lugar ocupado e ao papel exercido pelo político no modo de produção capitalista. Ao considerar o político como lugar da estrutura jurídico-política do Estado no modo de produção capitalista, Poulantzas concebe esse Estado como o reprodutor das relações de produção capitalista, ao exercer o seu papel de "coesão da unidade de uma formação social” (Poulantzas, 1970: 237) dividida em classes, na qual vigora esse modo de produção. Esse papel se deve graças à sua função repressiva bem como à ação do direito e do burocratismo (ligado a esse direito). Poulantzas analisa um duplo efeito ideológico produzido por esse tipo de Estado através da ação do direito e do burocratismo: o efeito de individualização ou efeito de isolamento e o efeito de unidade ${ }^{8}$.

O direito burguês, ao estabelecer o contrato individual de trabalho que garante a livre compra e venda da mercadoria força de trabalho, individualiza os agentes da produção, tornando-os sujeitos não pertencentes às classes sociais. Esse Estado tem a função de desorganizar politicamente as classes dominadas enquanto organiza - politicamente - as classes dominantes, graças a esse efeito de isolamento que incide sobre as relações econômicas. Compradores e vendedores de força de trabalho aparecem, nessa relação de compra e venda, como indivíduos isolados e iguais. Também a ideologia jurídica é a condição de possibilidade da relação jurídica de propriedade, ocultando as verdadeiras estruturas do econômico. Assim, na esfera da produção imediata, os trabalhadores estão separados dos meios de produção e isolados uns dos outros em função da divisão especificamente capitalista do trabalho (Poulantzas, 1970: 238; 274).

A ação do burocratismo é o que garante a produção do efeito de unidade: o burocratismo, através da seleção meritocrática dos seus funcionários, estabelece a relação desse Estado com as classes dominadas. O Estado capitalista se apresenta, pois, como a unidade do povo-nação, composto de pessoas políticas-

\footnotetext{
${ }^{8}$ Para uma discussão sobre a operacionalidade desses conceitos numa análise do funcionamento reprodutivo do "todo" social, veja-se o excelente artigo de Saes (1998, principalmente: 48-51), no qual e a partir do conceito nuclear de estrutura jurídico-política no modo de produção capitalista - formulado por Poulantzas - analisa os limites e as contradições internas da idéia da autonomia relativa do Estado capitalista, retificando e validando tal idéia.
} 
individuos privados (Poulantzas, 1970: 239). Essa função é desempenhada através da ocultação, aos olhos das classes dominadas, do seu caráter de classe e através da exclusão específica dessas classes das suas instituições (Poulantzas, 1970: 240). Tais pessoas políticas-indivíduos privados, isolados pelo efeito de individualização, estão "unificados na universalidade política do Estado-Nação". Essa reconstrução da unidade que garante a coesão das relações sociais se dá num plano imaginário (Poulantzas, 1970: 276) e só é possível, segundo Poulantzas, primeiramente, através da ação do aparato burocrático moderno, no interior do próprio aparelho de Estado. Esse aparato "não se apresenta diretamente como aparato de predomínio de classe, mas como a 'unidade', o princípio de organização e a encarnação do 'interesse geral' da sociedade” (a ocultação permanente do saber no seu interior é possível através da aplicação das regras hierárquicas e formais, em conseqüência do aparecimento da ideologia jurídico-política burguesa). Em segundo lugar, o efeito de unidade do povo-nação aparece "no funcionamento deste espaço particular do Estado capitalista, que é a cena política, lugar da representação política desse Estado considerado ... como Estado representativo moderno: apresentação do Parlamento enquanto 'representantes' da vontade popular, dos partidos enquanto 'representantes' da opinião pública, etc.” (Poulantzas, 1970: 277)'.

O Estado de tipo capitalista está, pois, organizado, institucionalmente, como se a luta de classes não existisse ${ }^{10}$. Assim, sua contradição principal, segundo Poulantzas, não consiste em na sua caracterização de "Estado de todo o povo" quando é, na verdade, "um Estado de classe”. Sua contradição principal consiste

\footnotetext{
${ }^{9}$ Para uma crítica aos elementos constitutivos da democracia burguesa, no que tange ao ceticismo produzido pela representação política sobre o conjunto de uma população determinada, vejase: Martorano (2005).

${ }^{10}$ É importante ressaltar que, enquanto em $O$ Estado e a revolução, Lênin defende a idéia de que “...o Estado é o produto inconciliável das contradições de classe” (1980b: 227), essa idéia não é retomada em Sobre o Estado. É possível, pois, a partir dos conceitos poulantzianos de efeito de direito capitalista, burocratismo, efeito de individualização e efeito de unidade, apontarmos que a função do Estado de tipo capitalista é muito mais complexa daquela apontada por Lênin naquela obra.
} 
"...em que se apresenta, em suas instituições mesmas, como Estado 'de classe' (das classes dominantes, que ele contribui a organizar politicamente) de uma sociedade institucionalmente estabelecida como não-dividida-em-classes; em que se apresenta como um Estado da classe burguesa, subentendendo que todo o "povo" forma parte dessa classe" (Poulantzas, 1970: 240).

Poulantzas (1975) ressalta ainda que mesmo que os membros do aparelho do Estado de tipo capitalista pertençam a classes diversas, agem de acordo com uma unidade interna específica e constituem essa categoria social específica: a burocracia, "servidora" da classe dominante pelo fato de a sua unidade interna derivar do papel objetivo do Estado que coincide com os interesses da classe dominante em virtude do próprio sistema. A relação entre a burguesia e o Estado é, pois, uma relação objetiva: a participação direta dos membros da classe dominante no aparelho de Estado é o efeito - e não a causa - dessa coincidência (Poulantzas, 1975: 19). O Estado capitalista “...só pode servir verdadeiramente à classe dominante até ao ponto em que seja relativamente autônomo em relação às várias frações dessa classe, com vista justamente a tornar-se capaz de organizar a hegemonia do conjunto da classe" (Poulantzas, 1975: 22) ${ }^{11}$.

E aqui importa ressaltar, como bem já o disse Saes (1998: 60-61) essa particularidade do Estado de tipo capitalista analisada por Poulantzas: a não coincidência dos membros do aparelho estatal com os proprietários dos meios de produção não é um mero acaso, pois ela se funda, justamente, na liberdade jurídica concedida ao produtor direto no nível da produção, o que o iguala, formalmente, ao proprietário dos meios de produção. Neste sentido, nenhum dos agentes do processo produtivo - convertidos, pela ação do direito, em sujeitos livres e iguais, portadores, portanto, de direitos - pode ser constrangido a não participar do corpo burocrático que constitui o aparelho de Estado. "O

\footnotetext{
${ }^{11}$ Quanto ao conceito de fração de classes e bloco no poder, veja-se: Poulantzas (1970), terceira parte: "Los rasgos fundamentales del Estado capitalista", capítulo 4: "El Estado capitalista y las classes dominantes".
} 
Estado", diria Poulantzas (1970: 241), "não é instrumento de classe, mas é o Estado de uma sociedade dividida em classes". Mas, repitamos, estes indivíduos-privados somente podem participar do aparelho estatal na condição de pessoas-políticas.

Mas, ao conceder a igualdade jurídica aos agentes da produção, o direito burguês possibilita a organização das classes dominadas em sindicatos, partidos, etc., para que suas reivindicações econômicas possam ser atendidas; porém, como ressalta Poulantzas (1970: 242), isto está inscrito “...como possibilidade nos limites próprios que [esse Estado] impõe à luta com direção hegemônica de classe" $" 12$.

Boito Jr. (2004: 76), ao concordar com a tese poulantziana de que o Estado "é o principal fator de coesão das formações sociais divididas em classes", também atribui ao Estado de tipo capitalista essa característica, ao ressaltar suas funções repressiva e ideológica - este aspecto, "quase sempre ignorado".

"De um lado, esse organismo detém o monopólio da força organizada, força que ostenta e mobiliza, quotidianamente, para a manutenção das relações de produção. Em situações de crise, essa força é utilizada de modo amplo e como último recurso para impedir a mudança social. De outro lado, o Estado secreta, permanentemente, as figuras ideológicas

\footnotetext{
${ }^{12}$ Isto significa que o mesmo direito, que estabeleceu a igualdade jurídica entre os proprietários e não proprietários dos meios de produção na sua relação de compra e venda da força de trabalho, concede, à classe trabalhadora, a oportunidade de organização através de sindicatos, partidos, etc., na defesa dos seus interesses de classe, o que não pode ser constatado nas formações sociais divididas em classes nas quais predominavam os modos de produção pré-capitalistas. Veja-se, a esse respeito, Boito Jr. (2001a: 77), artigo no qual encontramos uma interessante discussão sobre os motivos de o movimento sindical, enquanto "movimento reivindicativo estável, organizado e socialmente legítimo da classe dominada fundamental, visando a negociação das condições de exploração do trabalhador pelo proprietário dos meios de produção" somente poder existir nas formações sociais nas quais vigora o modo de produção capitalista.
} 
fundamentais para a reprodução mais ou menos pacífica das relações de produção" (Boito, 2004: 76) ${ }^{13}$.

Partindo da problemática ${ }^{14}$ comumente desenvolvida pela corrente althusseriana, Bettelheim (1969), ao propor a construção de uma teoria da transição socialista, entende que a expressão transição está longe de ser adequada à realidade que pretende designar, pois evoca um movimento linear e evolutivo cujo fim seria o socialismo. Portanto, a transição que importa analisar deve designar

“...um período histórico que se pode classificar mais justamente como o da "transição entre o capitalismo e o socialismo". Tal período não leva, linearmente, ao socialismo; pode levar, mas também pode levar a formas renovadas do capitalismo, principalmente ao capitalismo de Estado" (Bettelheim, 1969: 10).

E tal transição não pode ocorrer de forma linear porque um determinado modo de produção é dominante em sistemas sociais complexos. Neste sentido, afirma Bettelheim,

${ }^{13}$ Lênin (1980c: 176), ao iniciar sua conferência na universidade de Sverdlov, anuncia que a questão do Estado deve ser sempre revisitada, pois se trata de uma questão "básica" e "fundamental" de toda a política, de modo que “...não só em tempos tão agitados, tão tempestuosos, de revolução ... mas também nos tempos mais pacíficos, em qualquer jornal que trate de qualquer questão econômica ou política tropeçareis diariamente com a questão: o que é o Estado, em que consiste sua essência, em que consiste sua importância ...”. Penso que seria precipitado afirmar que Lênin, neste texto em particular, possui total clareza sobre a função do Estado na manutenção da ordem e da coesão de uma formação social na qual vigora o modo de produção capitalista a partir, não só da sua ação repressiva, mas, principalmente, da ação dos efeitos ideológicos que produz. De qualquer forma, fica a impressão de que Lênin já vislumbra - de maneira mais complexa que em $O$ Estado e a revolução - tal função do Estado de tipo capitalista.

${ }^{14}$ Boito Jr. (2004: 64), partindo das concepções althusserianas desenvolvidas nas décadas de 1960 e 1970, define problemática enquanto “...um conjunto de perguntas, idéias e suposições que delimitam o terreno no qual se produz uma determinada teoria, terreno que nem sempre é visível na superfície do discurso teórico, e que, no entanto, determina as condições e as possibilidades de enunciados desse discurso." 
“.... dissolução de um modo de produção apenas cria as condições do aparecimento de outro modo determinado. Não cria a necessidade deste, pois essa inscreve-se nas condições de transformação de uma estrutura muito mais complexa do que da estrutura econômica sozinha, ou seja, nas condições de transformação do conjunto da estrutura social e das superestruturas políticas e ideológicas" (Bettelheim, 1969: 24).

Essa definição de transição socialista de Bettelheim somente pode ser compreendida no interior do debate althusseriano das décadas de 1960 e 1970, justamente porque ela possui, como pressuposto, o desenvolvimento de uma teoria marxista da história que privilegia uma concepção ampliada de modo de produção, bem como o papel do político na reprodução de uma formação social com dominância do modo de produção capitalista ${ }^{15}$.

Balibar (1970), também ao partir do conceito de modo de produção ampliado para a compreensão de como se dá a transição de um modo de produção a outro, aponta a necessidade de correspondência, no nível da estrutura social total, entre o nível econômico e o nível jurídico-político e, no nível econômico, uma correspondência entre relações de propriedade e relações de apropriação material. Essas correspondências são necessárias para que a reprodução de um modo de produção determinado ocorra. As forças produtivas de um determinado modo de produção nunca entrariam, pois, em contradição direta com suas relações de produção, sendo que a contradição que possibilita a transformação social é "derivada e não originária" do modo de produção, ou seja, não está presente na estrutura, mas nos efeitos da estrutura ${ }^{16}$. Esta idéia está presente também em Althusser (1979: 87).

${ }^{15}$ Althusser desenvolve o conceito ampliado de modo de produção a partir da crítica, dentre outras, à concepção "economicista" sobre o funcionamento reprodutivo do "todo" social, que encontra guarida, por exemplo, no conhecido Prefácio de 59 de Marx. Veja-se, neste sentido, Saes (1998) e Boito Jr. (2004).

${ }^{16}$ Balibar critica justamente a tese do primado do desenvolvimento das forças produtivas contida no Prefácio de 59 de Marx. Neste texto, Marx defende a idéia de que num determinado estágio do desenvolvimento das forças produtivas, em um determinado modo de produção, as 
“[A]'contradição' é inseparável da estrutura do corpo social total no qual ela se exerce, inseparável de suas condições formais de existência, e das instâncias mesmas que governa, que ela própria é, portanto, no seu coração, afetada por elas, determinante, mas também determinada em um único e mesmo movimento, e determinada pelos diversos niveis e pelas diversas instâncias da formação social que ela anima: poderíamos dizer sobredeterminada em seu princípio."

É a reprodução ampliada, isto é, a dinâmica do modo de produção "que apresenta uma dimensão cumulativa: o desenvolvimento das forças produtivas" (Saes, 1998: 55) o que gera as contradições que poderão gerar os elementos do futuro modo de produção. Neste sentido, Saes, ao defender que a tese do desenvolvimento das forças produtivas se encontra presente na corrente althusseriana e desenvolvida principalmente por Balibar, aponta que o seu desenvolvimento em espiral, que ocorre "dentro dos limites impostos por relações de produção determinadas" acaba por transformar o que se apresenta, na sua origem, como um "sistema funcional de lugares diferenciados ... em operação no processo social de produção ... em classes sociais antagônicas” (Saes, 1998: 55).

Decorre dessa interpretação da reprodução ampliada do modo de produção a concessão da importância que cabe ao papel do político na transição, sendo a antecipação do político em relação à economia uma das etapas da transição, na qual "o modo de articulação das relações ... componentes da instância econômica, bem como das instâncias ... componentes da estrutura social total, não assume mais a forma de "limitação recíproca"; tal articulação se manifesta, agora, como "transformação de uma pelo efeito da outra" (Saes, 1998: 52).

Portanto, a transição só ocorre quando passar a existir uma relação de não-correspondência, de diacronia, no nível econômico, entre as relações de

forças produtivas entrariam em contradição com as relações de produção, rompendo-as e, portanto, iniciando um novo período de revoluções sociais. Não está contida nessa idéia o lugar do político e da política na transição de um modo de produção a outro. 
propriedade e relações de apropriação material e no nível da estrutura social a partir de um desajuste por antecipação do Estado frente à economia ${ }^{17}$; dito de outra forma, a transição “...se inicia pelo desajuste entre, de um lado, a estrutura jurídico-política do Estado que 'avançou' como resultado de uma revolução, e, de outro lado, a estrutura da economia ficou 'para trás', presa ao modo de produção anterior" (Boito Jr., 2004: 76).

Essa tese abre a possibilidade de pensarmos, pois, uma teoria do início da transição socialista (Bettelheim, 1969) - a revolução política - bem como do seu desenvolvimento.

"A economia do período de transição é portanto a que se segue a uma ruptura: por isso, a teoria da transição não é das origens, mas a do início. No sentido estrito da palavra, é a teoria do início de um novo modo de produção. Um dos seus objetivos é o estágio inicial, ou melhor, os problemas do período de instabilidade inicial (...) O que constitui em seguida a 'fase de transição' ... não é mais o fato da instabilidade ... é o fato de uma inadequaşão ainda relativamente grande entre o essencial das novas relações sociais..." (Bettelheim, 1969: 26-27).

Mas é importante ressaltar que os elementos que originam a possibilidade da revolução política levada a cabo pelo desenvolvimento da luta de classes, o que leva “à destruição da estrutura jurídico-política correspondente às relações de produção vigentes" e à "formação de uma nova estrutura jurídico-política defasada por 'antecipação' relativamente às relações de produção vigentes” são criados pelo desenvolvimento das forças produtivas, "ponto inicial" de uma "cadeia causal" que pode levar a essa transformação (Saes, 1998: 56). Ainda, segundo Saes, é o desenvolvimento das forças produtivas o que

\footnotetext{
${ }^{17}$ Boito Jr (2004: 76) faz, neste artigo, uma retificação desta concepção de Balibar, por ele não nos dizer, de um lado, “...qual a relação entre os dois tipos de não correspondência...” e, por outro, por apresentar, “...como antecipação do político frente ao econômico a intervenção política do Estado na acumulação primitiva ... que deveria ser considerada ... a pré-história do processo [do] modo de produção [capitalista], e não o processo de transição...”.
} 
possibilita, materialmente, tanto o desenvolvimento da luta política de classes como, após a revolução política, a implantação de novas relações de produção.

Portanto, a consolidação de um novo modo de produção não se limita a esse início. Ele depende da transformação do seu nível econômico e do seu desenvolvimento, pois, mesmo que ocorra a mudança da natureza política do Estado, a economia permanece vinculada às relações de produção anteriores, ou seja, em defasagem em relação ao político. A transição só ocorre se restabelecer a correspondência entre o político e o econômico, ou seja, se a economia se ajustar às relações políticas do novo Estado. Como bem ressaltou Boito Jr (2004: 78), é o Estado sob a ditadura do proletariado, "esse semiEstado" que poderia impedir o controle privado dos meios de produção, como também

\begin{abstract}
“...impulsionar, graças àquilo que podemos denominar a socialização do poder político, a socialização dos meios de produção: planejamento democrático unificado no centro e gestão operária da produção na base. É esse processo de supressão da propriedade privada e de instauração do controle coletivo do produtor direto sobre os meios de produção, iniciado pela revolução política, que pode restaurar a correspondência entre política e economia - ao fazer com que a socialização da economia avance até corresponder à socialização do poder político produzida pela revolução política do operariado" (Boito Jr., 2004: 78).
\end{abstract}

Se concordarmos com essa tese, podemos entender, por exemplo, que a Revolução Francesa de 1789 foi necessária para que houvesse a transformação do Estado Absolutista (que era feudal) em Estado capitalista. Segundo Boito Jr. (1998) essa transformação ocorreu para que esse Estado viabilizasse a substituição do trabalho feudal - obrigatório - pelo trabalho livre, condição central para o desenvolvimento das forças produtivas capitalistas, ou seja, condição para o desenvolvimento do mercado de compra e venda de força de trabalho e, portanto, para o desenvolvimento do próprio modo de produção capitalista. Portanto, as classes sociais que dirigiram tal processo 
revolucionário tiveram como causa de sua formação o processo de desenvolvimento (feudal) do comércio, das cidades e da manufatura, o que caracterizou os últimos séculos do feudalismo, de modo que o desenvolvimento das forças produtivas criou as condições, porém derivadas, para que essa transição ocorresse.

É possível considerar que a concepção leniniana de transição corresponde à tese da antecipação do político frente ao econômico, ou seja, a transformação do Estado capitalista, que se inicia com a revolução proletária, possibilitaria a mudança da base econômica capitalista sob a ditadura do proletariado.

Mas, como aconteceria, segundo Lênin, a supressão da divisão entre "trabalho manual e intelectual"? Ao que parece, nessa fase da transição, a tese do primado do desenvolvimento das forças produtivas passa a ocupar um lugar destacado no seu pensamento. Segundo Lênin (1986a), a socialização das forças produtivas já teria ocorrido devido à nova fase do capitalismo: a sua fase monopolista. Porém, o capitalismo retardaria o desenvolvimento das forças produtivas devido à existência da propriedade privada dos meios de produção. A expropriação da propriedade privada dos meios de produção, com base no desenvolvimento técnico já adquirido pelo capitalismo, daria possibilidade, como já foi exposto mais acima, a “...um desenvolvimento gigantesco das forças produtivas” (Lênin, 1980b, 287). E esse seria, portanto, o mérito da expropriação capitalista dos meios de produção. Como bem constatou Martorano (2002: 94-95)

"Vencer politicamente a burguesia e os latifundiários e derrotá-los militarmente até o seu desaparecimento como classe, são os termos, essencialmente descritivos, que Lênin utiliza para designar a primeira grande função do Estado socialista, que é apresentada como uma simples tarefa política."

Neste ponto cabe a seguinte pergunta: qual seria o principal papel da ditadura do proletariado neste processo de pleno desenvolvimento das forças produtivas? Fica subentendido que seria o de impulsionar esse desenvolvimento. 
Sistematizando o que até agora foi dito, a idéia que predomina nos escritos de Lênin é a de que a ditadura do proletariado iniciara a transição ao socialismo através da revolução política, o que possibilitou a repressão da classe dominante e a sua expropriação. Mas o decisivo para a realização dessa transição seria a "organização do registro e do controle" da produção e da distribuição dos produtos em escala nacional. E é isto o que possibilitaria a conquista da condição material de implantação do socialismo, ou seja, "a elevação da produtividade do trabalho em escala nacional”. (Lênin, 1980a: 564).

É neste sentido que o Estado proletário, de acordo com Lênin, teria que utilizar os especialistas burgueses nas fábricas, estes os portadores das relações capitalistas, para que o proletariado pudesse aprender a dominar a ciência e a técnica capitalistas. Lênin afirma também a necessidade de os trabalhadores vigiarem esses especialistas e que suas funções se limitariam a de meros técnicos ou organizadores. Nas suas palavras,

\begin{abstract}
"Sem a direção dos especialistas dos diferentes ramos do conhecimento, da técnica, da experiência, é impossível a transição para o socialismo, porque o socialismo exige um movimento de avanço consciente e massivo para uma produtividade do trabalho superior em comparação com o capitalismo e na base do que foi alcançado pelo capitalismo" (Lênin, 1980a: 566).
\end{abstract}

Lênin defende a necessidade das massas serem disciplinadas para o trabalho para que de fato se conseguisse uma elevação da produtividade e um desenvolvimento das forças produtivas. Essa disciplinarização ocorreria, pois, através da subordinação dos trabalhadores a um diretor único de fábrica e sua adoção é defendida sob o argumento de que somente através dessa subordinação (necessária à grande indústria mecanizada) é que se daria a organização da produção, o aumento da produtividade e a passagem ao socialismo. 
“...toda a grande indústria mecanizada - isto é, precisamente a fonte e a base material, produtiva, do socialismo - exige uma unidade de vontade absoluta e rigorosíssima que dirija o trabalho comum de centenas, milhares e dezenas de milhares de pessoas. Tanto tecnicamente como economicamente e historicamente esta necessidade é evidente e quantos pensaram no socialismo sempre a reconheceram como sua condição. Mas como pode ser assegurada a mais rigorosa unidade de vontade? - Por meio da subordinação da vontade de milhares à vontade de um só" (Lênin, 1980a: 581).

A defesa da necessidade do Estado proletário em utilizar os especialistas burgueses remete, pois, à idéia de uma técnica neutra, acima das relações sociais, pois esses técnicos, ao dirigirem o processo produtivo, reproduziriam as relações especificamente capitalistas de trabalho. Portanto, é necessário discordar da interpretação que defende que essas medidas concebidas e tomadas por Lênin somente tiveram sua razão de ser em virtude da atribulada conjuntura política e social na qual estava mergulhada a Rússia: guerra civil, Primeira Guerra mundial, fome, epidemia de tifo, etc. Não se pode negar, obviamente, a importância da influência desses acontecimentos no desenrolar de um processo revolucionário. Porém, não é possível limitar uma análise dos alcances e limites da transição socialista aos fatos conjunturais que assolam uma determinada formação social em processo de transformação ${ }^{18}$.

Logo, Lênin concebe a anarquia da produção, a existência de elementos pequeno-burgueses nas pequenas unidades produtivas, e, fundamentalmente, o atraso no desenvolvimento das forças produtivas como os principais entraves para a realização do socialismo.

Levando-se em consideração o que expomos até então, podemos entender que é no terreno teórico da primazia do primado do desenvolvimento das forças produtivas que Lênin defende a transformação econômica da sociedade russa sob a ditadura do proletariado. E, em virtude dessa concepção

${ }^{18}$ É o que tentei demonstrar, em decorrência da análise realizada sobre a concepção de Lênin do papel das forças produtivas e do taylorismo na transição socialista, em minha dissertação de mestrado. Veja-se, neste sentido, Lazagna (2002). 
sobre o papel do desenvolvimento das forças produtivas na transição socialista é que o taylorismo ganha um lugar privilegiado no seu pensamento, como a última palavra em avanço científico e tecnológico do capitalismo enquanto método para o aumento da produtividade ${ }^{19}$.

Lênin não deixa de considerar o taylorismo como uma "alavanca de exploração humana”. No entanto, tenta separar no taylorismo o que ele considera como sendo seus "aspectos positivos", ou seja, o aumento da produtividade gerado pela adoção do taylorismo reduziria o número de horas da jornada de trabalho, "liberando" o operariado, tanto para a vida política, através da realização das atividades de gestão estatal como para o controle da produção. O taylorimo também propiciaria, segundo Lênin, a padronização do trabalho manual para que todos tivessem a possibilidade de realizá-lo.

"A última palavra do capitalismo (...), o sistema Taylor - tal como todos os progressos do capitalismo - reúne em si toda a refinada crueldade da exploração burguesa e uma série de riquíssimas conquistas científicas no campo da análise dos movimentos mecânicos no trabalho, a supressão dos movimentos supérfluos e inábeis, a elaboração dos métodos de trabalho mais corretos, a introdução dos melhores sistemas de registro e controle, etc. A República Soviética deve adotar a todo o custo as conquistas mais valiosas da ciência e da técnica neste domínio. A possibilidade de realizar o socialismo é determinada precisamente pelos nossos êxitos na combinação do Poder Soviético e da organização soviética da administração com os últimos progressos do capitalismo. Tem de se criar na Rússia o estudo e o ensino do sistema Taylor, a sua experimentação e a adaptação sistemáticas" (Lênin, 1980a: 574).

Fica claro que taylorismo, para Lênin, está ligado aos avanços gerais do capitalismo, o que seria positivamente interpretado desde que tal método

\footnotetext{
${ }^{19} \mathrm{O}$ desenvolvimento dessa idéia só foi possível a partir do importante trabalho realizado por Linhart (1983). Veja-se, neste sentido, a segunda parte deste livro.
} 
pavimentasse o caminho para o socialismo. Neste sentido, a questão principal passa a ser a de quem poderia controlar e usar tal método de organização do trabalho. Sua resposta: o proletariado.

“O taylorismo, sem que o queiram seus autores e contra a
vontade destes, aproxima o tempo em que o proletariado
tomará em suas mãos toda a produção social e designará
suas próprias comissões, comissões operárias, para distribuir
e ordenar acertadamente todo o trabalho social. A grande
produção, as máquinas, as ferrovias, os telefones, tudo isto
oferece inúmeras possibilidades de reduzir quatro vezes o
tempo de trabalho dos operários organizados, assegurando-
lhes um bem-estar quatro vezes maior do que hoje. E as
comissões operárias, com a assistência dos sindicatos
operários, saberão aplicar estes princípios de distribuição
sensata do trabalho social quando este se vir livre da
escravização pelo capital” (Lênin, 1986b, p. 392, tradução
minha, A. L.).

Em virtude de uma concepção neutra das forças produtivas, Lênin não considera que a adoção de medidas capitalistas para o aumento da produtividade, dentre elas o taylorismo, o privilegiamento dos técnicos burgueses, a adoção do diretor único de fábricas, o incentivo à produtividade através dos salários por peça e prêmios de produtividade aos operários, etc., pudessem inviabilizar a realização do socialismo.

Mas, de acordo com Martorano (2002: 41), seria injusto afirmar que não está presente nas análises de Lênin uma preocupação com a necessidade de emergência do "trabalho socialista". No entanto, Lênin não esclarece o que seria esse trabalho, limitando-se, portanto, a caracterizá-lo como trabalho voluntário, sem remuneração, realizado para a sociedade e identificando-o com a experiência dos "sábados comunistas", experiência analisada no texto Uma grande iniciativa, o mesmo texto no qual Lênin aponta que a luta de classes continua no socialismo. É interessante notar que Lênin "intui" que uma transformação de tipo diferente deveria ocorrer no nível econômico para 
que o processo de transição socialista continuasse a se desenvolver. Quando afirma que a luta de classes no socialismo se dá "noutras condições, sob outras formas e com outros meios", percebemos que o que Lênin não conseguia superar era justamente sua visão neutra da ciência e da técnica capitalistas, de modo a não examinar a necessidade da transformação e, conseqüentemente, da superação da organização especificamente capitalista do trabalho, como o faz, por exemplo, Bettelheim (1979), ao analisar as iniciativas de superação das forças produtivas capitalistas no período da Revolução cultural chinesa. Gostaríamos, neste ponto, de abrirmos um parêntese para, resumidamente, referenciarmos a análise desse autor.

Bettelheim, ao analisar essa experiência constata que nela esteve presente a necessidade de se transformar as relações de produção, com ênfase no papel da superestrutura, especialmente da política, para que se colocasse a possibilidade de transformação da base econômica no processo de transição socialista. O que Bettelheim vê aflorar dessa experiência é que a política passa a permear a economia, o que possibilita a sua transformação pelos trabalhadores. Portanto, a tese da "política no posto de comando", tão difundida no período da Revolução cultural, objetivava submeter o resultado econômico aos objetivos políticos, ou seja, enfatizar a elevação da consciência política dos agentes sociais, sendo o aumento da produção uma conseqüência disto e não a prioridade. Nesse sentido, a politização dos trabalhadores não era considerada um entrave para a conquista de melhores resultados econômicos, pois sua criatividade era liberada no sentido de transformação dos instrumentos de trabalho e da maquinaria capitalistas. Também a tese da política da "Tríplice União" tinha o mesmo objetivo, ao defender que os quadros do partido, os técnicos e os operários participassem, juntos, da gestão das fábricas e do processo produtivo. Mas o que não se pode deixar de levar em consideração, tal qual o faz Bettelheim, é que, caso essa transformação das relações de produção não se realize em larga escala, a tendência é a do retorno do domínio das relações capitalistas de produção ${ }^{20}$.

\footnotetext{
${ }^{20}$ Sobre o processo de revolucionamento das forças produtivas na Revolução cultura chinesa, veja-se Fabrègues (1975a, 1975b e 1975c).
} 
Retornando, pois, às considerações de Lênin acerca do "trabalho socialista", pode-se dizer que Martorano (2002) tem razão quando aponta que a caracterização leniniana do trabalho socialista é insatisfatória, pois esse trabalho estaria identificado ao "...o trabalho voluntário, sem remuneração, realizado para a sociedade", não sendo, portanto, a sua "organização interna" o que lhe conferiria o caráter de socialista (Martorano, 2002: 46). Neste sentido, deve ficar claro que a compreensão de Lênin de trabalho socialista não comporta a necessidade de revolucionamento das forças produtivas capitalistas, ou seja, não leva em consideração a necessidade de incentivo às iniciativas das massas no sentido de quebrarem, num primeiro momento, no processo de produção imediato, a divisão especificamente capitalista do trabalho, ou seja, sua divisão técnica para posteriormente avançarem num processo de reorganização da produção sob as bases do desenvolvimento de forças produtivas socialistas.

O objetivo deste artigo foi, portanto, o de analisar, mesmo que de maneira não aprofundada, os avanços e limites das concepções leninianas sobre o papel do político e das forças produtivas na transição socialista. Nossas considerações visaram, portanto, contribuir para o desenvolvimento de uma teoria da transição socialista considerando-se, pois, que as reflexões de Lênin sobre o papel do político e da prática política no processo de transição do capitalismo ao socialismo fazem-se mais do que necessários para podermos afirmar que Lênin não compartilha da visão de um certo marxismo que, ao desconsiderar esse papel da política na teoria marxista da história, concebe a mudança histórica como simples reflexo de uma mudança econômica prévia, estando, portanto, este marxismo situado no terreno do economicismo que caracterizou, por exemplo, tanto a social democracia quanto o comunismo no século XX. É este economicismo que encampa a primazia do desenvolvimento das forças produtivas, ou seja, que elas permanecem separadas dos mais diversos modos de produção - o escravista, o feudal, o capitalista - existindo, portanto, um "grau”, um "nível” do seu desenvolvimento, como se houvesse uma escala supra-modal desse desenvolvimento, que o relacionaria a cada modo de produção. É importante ressaltar que o economicismo não compartilha da visão de que cada modo de produção 
engendra suas próprias forças produtivas, no quadro de relações de produção determinadas.

Lênin se diferencia deste economicismo ao defender que a luta revolucionária é um pré-requisito para a transição ao socialismo. Mas, como se tentou demonstrar, ao considerar que a técnica e a ciência capitalistas poderiam ser despidas de suas características capitalistas quando meramente impulsionadas - e não transformadas - pela classe trabalhadora, Lênin se depara com a dificuldade de superação, como ele mesmo afirma, de uma das principais contradições do modo de produção capitalista, ou seja, a separação entre trabalho de direção e trabalho de execução.

$* * * * *$

\begin{abstract}
This paper will seek to apprehend the place of politics in the thought of Lenin, in the reproduction of the capitalist mode of production and in the socialist transition. Based on a critic to the technological determinism, it will then discuss the role of the productive forces and of Taylorism in the thought of Lenin and in the socialist transition. These reflections will be grounded on some concepts developed by the protagonists in the debate promoted by the Althusserian trend, in the 1960s and 1970s, and by authors who formulated such concepts about the place of politics in the Marxist theory of history.
\end{abstract}

Keywords: Productive forces, State, Politics, Transition, Socialism.

\title{
REFERÊNCIAS BIBLIOGRÁFICAS
}

ALTHUSSER, Louis (1979). A favor de Marx. 2. ed. Rio de Janeiro: Zahar Editores, 1979.

ALTHUSSER, Louis; BALIBAR, Étienne (1970). Para leer El Capital. 4. ed. Buenos Aires: Siglo XXI.

BETT'TELHEIM, Charles. A transição para a economia socialista. Rio de Janeiro: Zahar Editores, 1969. 
BET'TELHEIM, Charles. Revolução cultural e organização industrial na China. Rio de Janeiro: Edições Graal, 1979.

BOITO JR., Armando. "Os tipos de Estado e os problemas das análises poulantzianas”. Crítica Marxista. São Paulo, no 07, p. 67-88, 1998.

BOITO JR., Armando. “Comuna republicana ou operária? A tese de Marx posta à prova”. In: BOITO JR., Armando (org.). A Comuna de Paris na história. São Paulo; Campinas: Xamã; Cemarx/IFCH/UNICAMP, 2001.

BOITO JR., Armando. "Pré-capitalismo, capitalismo e resistência dos trabalhadores: nota para uma teoria da ação social". Critica Marxista, São Paulo, no 12, p. 77-104, 2001a.

BOITO JR., Armando. "O lugar da política na teoria marxista da história". Crítica Marxista. Rio de Janeiro, no 19, p. 62-81, 2004.

BORON, Atilio. Filosofia política marxista. São Paulo: Cortez, 2003.

FABRÈGUES, Bernard. “Organisation capitaliste et organisation socialiste du travail". Comunisme. Paris, no 16-17, 1975a.

FABRÈGUES, Bernard. “Organisation capitaliste et organisation socialiste du travail (II): le developpement du machinisme par le capitalisme”. Comunisme. Paris, no 18, 1975b.

FABRÈGUES, Bernard. "Organisation capitaliste et organisation socialiste du travail (III). Chine: machinisme, science e technique". Comunisme. Paris, no 19, 1975c.

LAZAGNA, Angela. Lenin, as forças produtivas e o taylorismo. Campinas, Dissertação (Mestrado em Sociologia) - Instituo de Filosofia e Ciências Humanas, Universidade Estadual de Campinas, 2002.

LAZAGNA, Angela. "Resenha: Balanço do debate: a transição do feudalismo ao capitalismo”. Crítica Marxista. Rio de Janeiro, no 20, p. 182-185, 2005 a.

LAZAGNA, Angela. "A problemática das forças produtivas no pensamento de Lênin”. Cadernos Cemarx. Campinas, no 02, vol. 01, pp. 21-29, 2005 b. 
LENIN, V. I. "As tarefas imediatas do poder soviético". In: Obras escolhidas. São Paulo: Alfa-Ômega, vol. 02, [1918], 1980a.

LENIN, V. I. “O Estado e a Revolução”. In: Obras escolbidas. São Paulo: AlfaÔmega, vol. 02, [1917], 1980b.

LENIN, V. I. "Sobre o Estado: conferência na universidade Sverdlov. 11 de julho de 1919”. In: V. I. Lênin. Obras escolbidas. São Paulo: Alfa e Ômega, vol. 3, [1919], 1980c.

LENIN, V. I. "Uma grande iniciativa”. In: Obras escolbidas. São Paulo: AlfaÔmega, vol. 03v, [1919], 1980d.

LENIN, V. I. “Imperialismo, fase superior do capitalismo”. In: Obras escolbidas. São Paulo: Alfa-Ômega, vol. 01, [1916], 1986 a.

LENIN, V. I. "El taylorismo es la esclavización del hombre por la maquina". In: Obras completas. Moscú: Editorial Progreso, t. 24, [1914], 1986 b.

LINHART, Robert. Lênin, os camponeses, Taylor. Rio de Janeiro. Ed. Marco Zero, 1983.

MARIUT'TI, Eduardo Barros. Balanço do debate: a transição do feudalismo ao capitalismo. São Paulo, Hucitec, 2004.

MARTORANO, Luciano C. "Elementos do Estado socialista na Comuna de Paris". In: BOITO JR. Armando (org.). A Comuna de Paris na história. São Paulo; Campinas: Xamã; Cemarx/IFCH/UNICAMP, 2001.

MARTORANO, Luciano C. A Burocracia e os desafios da transição socialista. São Paulo: Anita Garibaldi/Xamã, 2002.

MARTORANO, Luciano C. "Democracia burguesa e apatia política". In: Documento eletrônico: www.unicamp.br/cemarx, 2005.

POULANTZAS, Nicos. Poderpolitico y clases sociales en el Estado Capitalista. 2. ed. México: Siglo XXI, 1970. 
POULANTZAS, Nicos; MILIBAND, Ralph. Debate sobre o Estado capitalista. Porto: Edições Afrontamento, 1975.

QUARTIM DE MORAES, João. "Marx, Engels e Lênin perante a Comuna". In: BOITO JR. Armando (org.). A Comuna de Paris na história. São Paulo; Campinas: Xamã; Cemarx/IFCH/UNICAMP, 2001.

SAES, Décio. "A questão da autonomia relativa do Estado em Poulantzas". Crítica Marxista. São Paulo, no 07, p. 46-66, 1998.

SAES, Décio. "Marxismo e história". Crítica Marxista. São Paulo, no 01, p. 3959, 1994.

SWEEZY, Paul et al. Do fendalismo ao capitalismo. São Paulo: Martins Fontes, 1977.

VANZULLI, Marco. "Sobre a teoria marxiana da história nas 'Formações econômicas pré-capitalistas"'. Crítica Marxista. Rio de Janeiro, no 22, pp. 97-108, 2006. 